\title{
Evaluation of steroidogenic capacity after follicle stimulating hormone stimulation in bovine granulosa cells of Revalor $200^{\circledast}$ implanted heifers
}

Andrea D Stapp ${ }^{1}$, Craig A Gifford ${ }^{1}$, Dennis M Hallford ${ }^{2}$ and Jennifer A Hernandez Gifford ${ }^{1,3 *}$

\begin{abstract}
Background: Heifers not used as breeding stock are often implanted with steroids to increase growth efficiency thereby altering hormone profiles and potentially changing the environment in which ovarian follicles develop. Because bovine granulosa cell culture is a commonly used technique and often bovine ovaries are collected from abattoirs with no record of implant status, the objective of this study was to determine if the presence of an implant during bovine granulosa cell development impacts follicle stimulating hormone-regulated steroidogenic enzyme expression. Paired ovaries were collected from 16 feedlot heifers subjected to 1 of 3 treatments: non-implanted ( $(n=5)$, Revalor 200 for $28 d(n=5)$, or Revalor 200 for $84 d(n=6)$. Small follicle ( 1 to $5 \mathrm{~mm})$ granulosa cells were isolated from each pair and incubated with phosphate buffered saline $(n=16)$ or $100 \mathrm{ng} / \mathrm{mL}$ follicle stimulating hormone $(n=16)$ for $24 \mathrm{~h}$.

Results: Granulosa cells of implanted heifers treated with follicle stimulating hormone produced medium concentrations of progesterone similar $(P=0.22)$ to non-implanted heifers, while medium estradiol concentrations were increased $(P<0.10)$ at 28 and $84 \mathrm{~d}$ compared to non-implanted heifers indicating efficacy of treatment. Additionally, real-time PCR analysis in response to follicle stimulating hormone treatment demonstrated a decrease in steroidogenic acute regulatory protein $(P=0.05)$ mRNA expression in heifers implanted for $84 \mathrm{~d}$ and an increase in P450 side chain cleavage mRNA in granulosa cells of heifers implanted for $28(P<0.10)$ or $84 \mathrm{~d}(P<0.05)$ compared to non-implanted females. However, no difference in expression of 3-beta-hydroxysteroid dehydrogenase $(P=0.57)$ and aromatase $(P=0.23)$ were demonstrated in implanted or non-implanted heifers.

Conclusions: These results indicate follicles which develop in the presence of high concentrations of androgenic and estrogenic steroids via an implant tend to demonstrate an altered capacity to respond to follicle stimulating hormone stimulation. Thus, efforts should be made to avoid the use of implanted heifers to study steroidogenesis in small follicle granulosa cell culture systems.
\end{abstract}

Keywords: Bovine, Follicle stimulating hormone, Granulosa cells, Implant, Steroidogenesis

\section{Background}

Combination trenbolone acetate (TBA) and estradiol-17 $\beta$ $\left(E_{2}\right)$ implants are commonly used in feedlot cattle to increase feed efficiency and muscle mass [1]. However, exposure to exogenous hormones also influences other physiological functions. SJ Jones, RD Johnson, CR Calkins and ME Dikeman [2] demonstrated that implanted bulls had reduced cortisol and testosterone serum concentrations

\footnotetext{
* Correspondence: jah.hernandez_gifford@okstate.edu

${ }^{1}$ Department of Animal Science, Oklahoma State University, Stillwater, OK 74078, USA

Full list of author information is available at the end of the article
}

and smaller testicular size compared to non-implanted bulls. These data indicate that combination implants alter adrenal and gonadal steroid production and normal gonadal development.

In females, elevated concentrations of hormones, including estradiol, can alter ovarian function and steroid hormone synthesis. Anabolic agents used to enhance growth inhibit pituitary release of gonadotropins [3] as a result of the androgenic activity as exhibited by TBA [4] or the estrogenic activity [5]. Consequently, implanting developing heifers has marked impacts on reproductive function. Heifers receiving a TBA and $E_{2}$ implant at $84 \mathrm{~d}$ of age had 
delayed puberty and retardation in reproductive tract development [6]. Ewes prenatally treated with testosterone during mid-gestation did not display a delay in onset of puberty but demonstrated absent or disrupted progestogenic cycles, and had larger follicles with prolonged presence [7]. Heifers receiving a TBA implant at estrus or d 13 of the estrous cycle were anestrus for a period of time during growth promotant release, thereafter d 13 implanted heifers remained anestrus due to follicle or luteal cysts [8].

Though steroid implants are not intended for use in breeding females, bovine ovaries are often harvested from abattoirs for GC culture to investigate mechanisms regulating follicle maturation and differentiation. To our knowledge there is no study demonstrating the impact of elevated levels of androgens and estrogens on the developing follicle. Therefore, the objective of this study was to determine if the presence of anabolic and estrogenic steroids impacts follicle stimulating hormone (FSH)-regulated steroidogenic enzyme expression.

\section{Methods \\ Animals}

All procedures involving animals were approved by the Oklahoma State University Institutional Animal Care and Use Committee (AG-12-4). Sixteen predominantly Angus heifers $(361 \mathrm{~kg})$ were randomly assigned to one of three implant groups: non-implanted $(n=5)$, implanted for $28 \mathrm{~d}$ with a combination implant (200 mg TBA + $20 \mathrm{mg} \mathrm{E}_{2}$; Revalor $200^{\circ}$; Intervet, Inc., Millsboro, DE, USA; 28 d; $\mathrm{n}=5)$, and $84 \mathrm{~d}$ with Revalor $200^{\circ}(84 \mathrm{~d} ; \mathrm{n}=6)$. Assigned heifers were implanted on d 0 (group implanted for $84 \mathrm{~d}$ ) or d 56 (group implanted for $28 \mathrm{~d}$ ) and were not reimplanted. Heifers were harvested on d 84 and 85 and paired ovaries were harvested (Robert M. Kerr Food and Agriculture Products Center, Oklahoma State University, Stillwater, OK) from each heifer for GC collection and culture.

\section{Granulosa cell culture}

Small follicle (1 to $5 \mathrm{~mm}$ ) GC were isolated from ovaries of each animal and each animal's GC were cultured separately using methods previously described [9]. Follicle size selection was based on the intent of investigating FSH signaling cascades in implanted and non-implanted heifers. Previous observations indicate that 1 ) recruitment of bovine follicles able to respond to FSH occurs at a diameter of 1 to $3 \mathrm{~mm}$ [10]; 2) GC acquire FSH receptors prior to follicular recruitment [11,12]; and 3) GC of recruited follicles express steroidogenic enzyme mRNAs before LH receptor mRNA is detected [13]. Briefly, GC were resupended and washed twice in short-term media (1:1 mixture of Dulbecco's Modified Eagle Medium (DMEM) and Ham's F12 containing $0.12 \mathrm{mmol} / \mathrm{L}$ gentamycin and $38.5 \mathrm{mmol} / \mathrm{L}$ sodium bicarbonate) obtained from Sigma-Aldrich (St. Louis, MO,
USA). After the final wash, cells were re-suspended in 0.5 to $2 \mathrm{~mL}$ of resuspension medium (serum-free medium with $2.5 \mathrm{mg} / \mathrm{mL}$ collagenase and $1 \mathrm{mg} / \mathrm{mL}$ DNase) (SigmaAldrich) to prevent cell clumping prior to plating. Cell number and viability were determined via hemocytometer using trypan blue dye exclusion. Granulosa cells from each animal were seeded in two-60-mm culture dishes at a density of $5.2 \times 10^{5}$ cells in DMEM complete medium (1:1 DMEM and Ham's F-12 containing 10\% fetal bovine serum, $0.12 \mathrm{mmol} / \mathrm{L}$ gentamycin, $2.0 \mathrm{mmol} / \mathrm{L}$ glutamine, and $38.5 \mathrm{mmol} / \mathrm{L}$ sodium bicarbonate). Incubation of cells occurred at $38.5^{\circ} \mathrm{C}$ and $5 \% \mathrm{CO}_{2}$ and medium was changed every 24 h until cell confluency reached $70-75 \%$. Once confluency was reached, medium and unattached cells were removed. To test how each animal's GC responded to FSH treatment, one culture dish of GC from each animal were incubated with phosphate buffered saline (PBS; Con; $\mathrm{n}=16$ ) in serum free media supplemented with $10^{-7} \mathrm{~mol} / \mathrm{L}$ testosterone propionate (Sigma-Aldrich) for $24 \mathrm{~h}$, allowing each animal to serve as its own control. The second culture dish was treated with $100 \mathrm{ng} / \mathrm{mL}$ purified human $\mathrm{FSH}$ (S1AFP-B-3; National Hormone and Peptide Program, National Institute of Diabetes and Digestive and Kidney Diseases, National Institutes of Health, Bethesda, MD, USA; $n=16$ ) in serum free media supplemented with $10^{-7} \mathrm{~mol} / \mathrm{L}$ testosterone propionate (Sigma-Aldrich) for $24 \mathrm{~h}$. Treatment medium was collected and frozen at $-80^{\circ} \mathrm{C}$ until analysis. Treatments were terminated by removing medium and rinsing cells once with ice cold PBS. Cells were scraped into $1 \mathrm{~mL}$ TRIzol (Invitrogen, Grand Island, NY, USA) reagent and stored at $-80^{\circ} \mathrm{C}$ until isolation of RNA.

\section{RNA extraction and quantitative real-time PCR}

RNA was isolated from cultured GC using TRIzol reagent according to the manufacturer's protocol and stored at $-80^{\circ} \mathrm{C}$. Integrity of RNA was assessed by visualization of $18 \mathrm{~S}$ and $28 \mathrm{~S}$ ribosomal RNA resolved by agarose gel electrophoresis. RNA purity and quantity was determined using a NanoDrop, ND 1000 Spectophometer (Thermo Fisher Scientific, Wilmignton, DE, USA). Purity was determined by $260 / 280 \mathrm{~nm}$ absorbance ratios, absorbance ratios above 1.8 were considered acceptable. Total RNA $(1 \mu \mathrm{g})$ was treated with $1 \mu \mathrm{L}$ DNase I Amplification Grade (Invitrogen) to remove genomic DNA contamination following manufacturer's instructions. First strand cDNA was synthesized from total RNA using oligo(dT) primers and $1 \mu \mathrm{L}$ Superscript II Reverse Transcriptase (Invitrogen) for each FSH-treated and non-treated samples. Samples were stored at $-20^{\circ} \mathrm{C}$ until analysis. All gene specific primers were designed using Primer3 [14] and synthesized by Integrated DNA Technologies (Coralville, IA, USA). Forward and reverse primer 
sequences are listed in Table 1 . Primers were validated at a concentration of $300 \mathrm{nmol} / \mathrm{L}$ using a 7-log dilution curve as previously reported [15].

A working solution of cDNA was prepared by diluting 1:10 with DEPC-treated water. Five microliters of cDNA working solution was added to $20 \mu \mathrm{L}$ master mix containing $13 \mu \mathrm{L}$ SYBR green and fluorescein mix (Bioline, Taunton, MA, USA) and $0.75 \mu \mathrm{L}$ of each forward primer $(10 \mu \mathrm{mol} / \mathrm{L})$ and reverse primer $(10 \mu \mathrm{mol} / \mathrm{L})$. Real-time PCR analysis for each sample was carried out in duplicate using a CFX real-time PCR detection system (Bio-Rad Laboratories, Hercules, CA, USA). Standard thermocycler conditions were as follows: $95^{\circ} \mathrm{C}$ for $10 \mathrm{~min}$, followed by 40 cycles of $95^{\circ} \mathrm{C}$ for $15 \mathrm{~s}, 60^{\circ} \mathrm{C}$ for $30 \mathrm{~s}$, and $72^{\circ} \mathrm{C}$ for $30 \mathrm{~s}$. Relative fold change in target mRNAs was quantified using the $\Delta \Delta \mathrm{Cq}$ method where the $\mathrm{FSH}$ $\Delta \Delta \mathrm{Cq}$ for each animal was determined by subtracting each animals Con $\Delta \mathrm{Cq}$ from their FSH $\Delta \mathrm{Cq}$ [16]. All reverse-transcribed cDNA samples were assayed in duplicate for each gene, and melt curve analyses were performed to ensure specificity of amplification. Melt curve analysis was carried out for 81 cycles with $0.5^{\circ} \mathrm{C}$ temperature increase from $55^{\circ} \mathrm{C}$ to $95^{\circ} \mathrm{C}$.

To determine the appropriate reference gene to normalize cDNA variability between samples, a panel of three reference genes was analyzed including, glyceraldehyde-3-phosphate dehydrogenase (GAPDH), cyclophilin A (PPIA), and mitochondrial ribosomal protein L19 (MRPL19). The raw Cq values were obtained for each gene in all samples and analyzed using GeNorm (Biogazell qbasePLUS2, Zwijnaarde, Belgium) to determine the most stable normalization factor. The most stable housekeeping gene for target gene normalization was determined to be GAPDH and was used as the reference gene [17].

\section{Radioimmunoassay}

Granulosa cell culture medium was analyzed for $E_{2}$ and progesterone $\left(\mathrm{P}_{4}\right)$ by solid-phase radioimmunoassay using components of Siemens Medical Diagnostics Corp (Los Angeles, CA, USA) commercial kits as previously described [9]. The $\mathrm{E}_{2}$ concentration in samples of cell culture medium was determined in $200 \mu \mathrm{L}$ of medium and the specific binding was $62.5 \%$. Detection limit (95\% of maximum binding) of the assay was $2 \mathrm{pg} / \mathrm{mL}$. Intra-assay $\mathrm{CV}$ for $\mathrm{E}_{2}$ was $6.5 \%$ for cell culture medium. The $\mathrm{P}_{4}$ concentration in samples of GC medium was assayed at $10 \mu \mathrm{L}$. The specific binding was $58.8 \%$. Detection limit (95\% of maximum binding) of the assay was $0.1 \mathrm{ng} / \mathrm{mL}$. Intra-assay $\mathrm{CV}$ for $\mathrm{P}_{4}$ was $4.1 \%$ for cell culture medium.

\section{Statistical analysis}

Experiments were analyzed by analysis of variance for a completely randomized design in which three treatments were included; non-implanted $(n=5)$, Revalor $200^{\circ}$ for $28 \mathrm{~d}(\mathrm{n}=5)$, and Revalor $200^{\circ}$ for $84 \mathrm{~d}(\mathrm{n}=6)$. Relative fold changes in gene expression for steroidogenic acute regulatory protein $(S T A R), 3 \beta$-hydroxysteroid dehydrogenase $(3 \beta-H S D), \mathrm{P} 450$ side chain cleavage (CYP11A1), and aromatase (CYP19A1) mRNA, and medium hormonal concentration of $\mathrm{P}_{4}$ and $\mathrm{E}_{2}$ are presented as the least square means \pm standard error of the mean. For all culture experiments, GC from each animal were kept separate and each animal's GC were subjected to either control treatment or FSH treatment. Thus, fold change values are each animal's FSH response relative to that animal's non-treated controls. A value in CYP11A1 mRNA expression of a non-implanted heifer at least three standard deviations from the mean and a missing fold change for CYP19A1 in the $84 \mathrm{~d}$ treatment group were excluded from statistical analysis. Quantitative realtime PCR data and hormone concentrations were

Table 1 Primer sequences used in real-time PCR

\begin{tabular}{|c|c|c|c|}
\hline \multirow[b]{2}{*}{ Gene } & \multirow[b]{2}{*}{ Accession no. } & \multicolumn{2}{|c|}{ Sequences of primers $\left(5^{\prime}-3^{\prime}\right)$} \\
\hline & & Forward & Reverse \\
\hline${ }^{1} 3 \beta-H S D$ & NM_174343 & CCACACCAAAGCTACGATGA & GCAAGCCAGTACTGCAGAGA \\
\hline${ }^{2} \mathrm{CYP} 11 \mathrm{~A} 1$ & NM_176644 & AAGTITGACCCAACCAGGTG & GTGGATGAGGAAGAGGGTCA \\
\hline${ }^{3}$ CYP19A1 & NM_174305 & CAACAGCAGAGAAGCTGGAAGACA & CACCCACAACAGTCTGGATTTCCCT \\
\hline${ }^{4} \mathrm{GAPDH}$ & NM_001034034 & GGGTCATCATCTCTGCACCT & GGTCATAAGTCCCTCCACGA \\
\hline${ }^{5} M R P L 19$ & NM_001046068 & GGAAAGCAGGTTCTTGAGTCC & TGGCATATGGGTCAGCAGTA \\
\hline${ }^{6} P P I A$ & XM_002690515 & GGTACTGGTGGCAAGTCCAT & GCCATCCAACCACTCAGTCT \\
\hline${ }^{7} S T A R$ & BC110213 & CCCATGGAGAGGCTITATGA & CGTGAGTGATGACCGTGTCT \\
\hline
\end{tabular}

${ }^{1} 3 \beta-H S D=3 \beta$-hydroxysteroid dehydrogenase.

${ }^{2}$ CYP11A1 $=$ P450 side chain cleavage.

${ }^{3}$ CYP19A1 = aromatase.

${ }^{4} \mathrm{GAPDH}=$ glyceraldehyde-3-phosphate dehydrogenase.

${ }^{5} M R P L 19=$ mitochondrial ribosomal protein L19.

${ }^{6} P P I A=$ cyclophilin $\mathrm{A}$.

${ }^{7} S T A R=$ steroidogenic acute regulatory protein. 
analyzed using the GLM procedures of SAS (SAS Institute, Cary, NC, USA). Data were tested for homogeneity of variance using Hartley's F max test and STAR and $\mathrm{E}_{2}$ were corrected by $\log$ transformation $(\log +3$ and $\log +$ 1 , respectively). When a significant treatment effect was observed, means were separated using the least significant test computed by the predicted difference option of SAS. Statistical significance was set at $P<0.10$.

\section{Results and discussion}

The anabolic effects of implants are likely a consequence of altering the endogenous hormonal milieu. This concept is supported by the demonstrated increase in plasma $\mathrm{GH}$ concentrations in response to $E_{2}$ [18] or TBA and $E_{2}$ [19] implants. High levels of anabolic hormones can also modulate reproduction as demonstrated by TBA induced anestrus in cows $[8,20]$ and delayed puberty and decreased fertility in TBA plus $E_{2}$ implanted heifers compared to non-implanted controls [6,21].

To determine the steroidogenic capacity of small follicle GC from an environment of elevated anabolic steroids, we first evaluated steroid accumulation in cell culture medium. Hormonal output was analyzed via radioimmunoassay. The ability of cultured GC to synthesize $\mathrm{P}_{4}$ was not affected by heifer implant status $(P=0.22$; Figure $1 \mathrm{~A})$. These results are similar to previous studies in which bovine GC were cultured with $200 \mathrm{ng} / \mathrm{mL} \mathrm{FSH}$ and also did not show an effect on production of $\mathrm{P}_{4}$ in cell culture medium compared to controls [22]. As expected, FSH treated GC had increased $(P<0.01)$ concentrations of $E_{2}$ compared to PBS-treated controls (Figure 1B) demonstrating successful induction of the FSH signaling pathway. Additionally, GC from heifers implanted for $28 \mathrm{~d}$ or $84 \mathrm{~d}$ produced greater concentrations of $\mathrm{E}_{2}$ (78 and $80 \pm 21 \mathrm{pg} / \mathrm{mL}$, respectively) compared to non-implanted heifers $(26 \pm 21 \mathrm{pg} / \mathrm{mL}$; $P<0.10$; Figure 2B) in response to FSH.

Based on the apparent change in estrogen production as a result of implant status and that estrogen production by the follicle is determined by $\mathrm{FSH}$ regulation of genes encoding key steroidogenic enzymes, we next evaluated gene expression of the steroidogenic enzymes of non-implanted and implanted heifers in response to FSH. Analysis of steroidogenic enzyme mRNAs of pubertal heifers implanted with TBA and $E_{2}$ in the presence or absence of FSH demonstrated differences in expression as compared to non-implanted heifers. The first rate limiting step in steroid synthesis is the delivery of cholesterol to the inner mitochondrial membrane which is mediated by steroid acute regulatory protein $(S T A R)$. Expression of STAR was reduced $(P<0.05)$ in response to FSH in cells from heifers exposed to TBA and $E_{2}$ for $84 \mathrm{~d}$ when compared to non-implanted heifers and heifers implanted for $28 \mathrm{~d}$ (Figure 2A). STAR

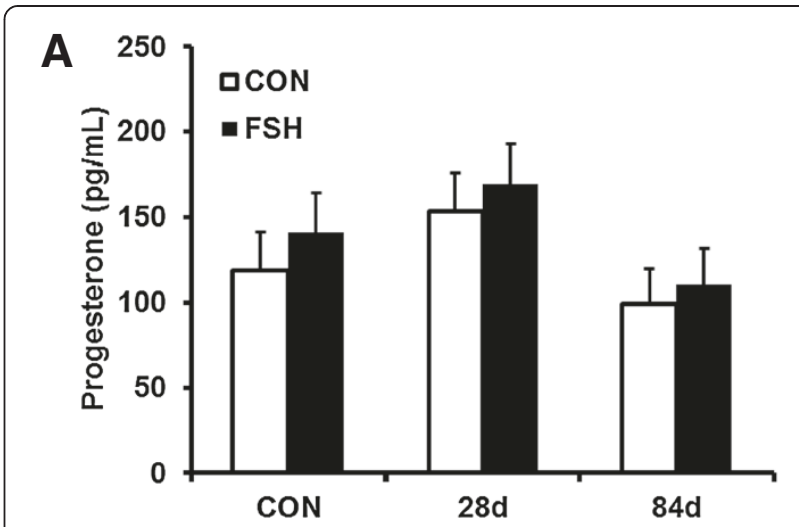

B

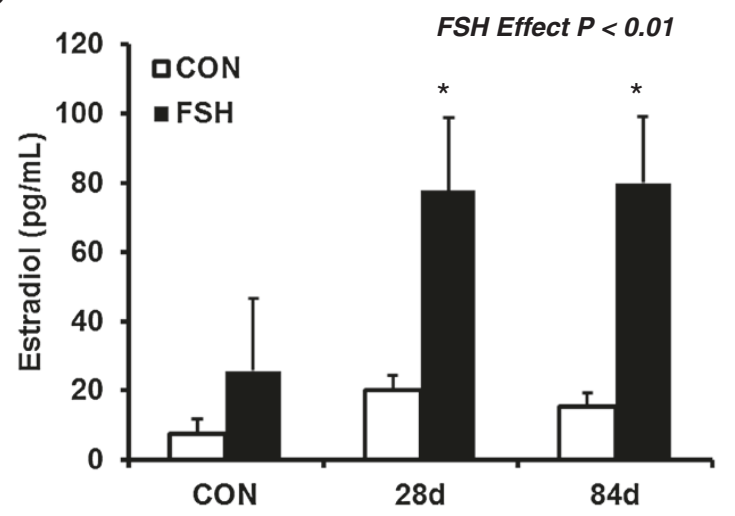

Figure 1 Anabolic androgens and estrogens did not affect progesterone $\left(P_{4}\right)$ production but increased estradiol $\left(E_{2}\right)$ concentrations. Small follicle granulosa cells from non-implanted heifers $(n=5)$ or heifers implanted for $28 d(n=5)$ or $84 d(n=6)$ were treated for $24 \mathrm{~h}$ with FSH (100 ng/mL, $24 \mathrm{~h}$ ) or PBS, subsequently cell culture medium were analyzed by RIA. (A) Combination implants of TBA and $E_{2}$ did not affect the ability of granulosa cells to produce $\mathrm{P}_{4}$. (B) Medium $\mathrm{E}_{2}$ concentrations were greater in cells exposed to FSH $(P<0.01)$ compared to non-treated controls indicating successful FSH treatment. Additionally, medium $E_{2}$ concentrations increased $(P<0.10)$ in granulosa cells from implanted heifers compared with non-implanted. Concentration is presented as the least square mean \pm pooled standard error. Results are compared within FSH treatment group. ${ }^{*} P<0.10$ indicates a significant difference when compared with non-implanted heifers.

is fundamental to the biosynthesis of steroid hormones as it provides cholesterol to the cytochrome P450 sidechain cleavage enzyme (CYP11A1). Mitochondrial $C Y P 11 A 1$ catalyzes the cleavage of the cholesterol side chain to form pregnenolone and this reaction represents the first committed step in steroidogenesis. Follicle stimulating hormone increased mRNA expression of CYP11A1, in GC from $28 \mathrm{~d}(P<0.10)$ and $84 \mathrm{~d}(P<0.05)$ implanted heifers as compared to non-implanted (Figure 2B). Studies indicate that both delivery of cholesterol to the enzyme system and the expression of CYP11A1 are important factors controlling the rate of steroid hormone synthesis [23] and may contribute to 


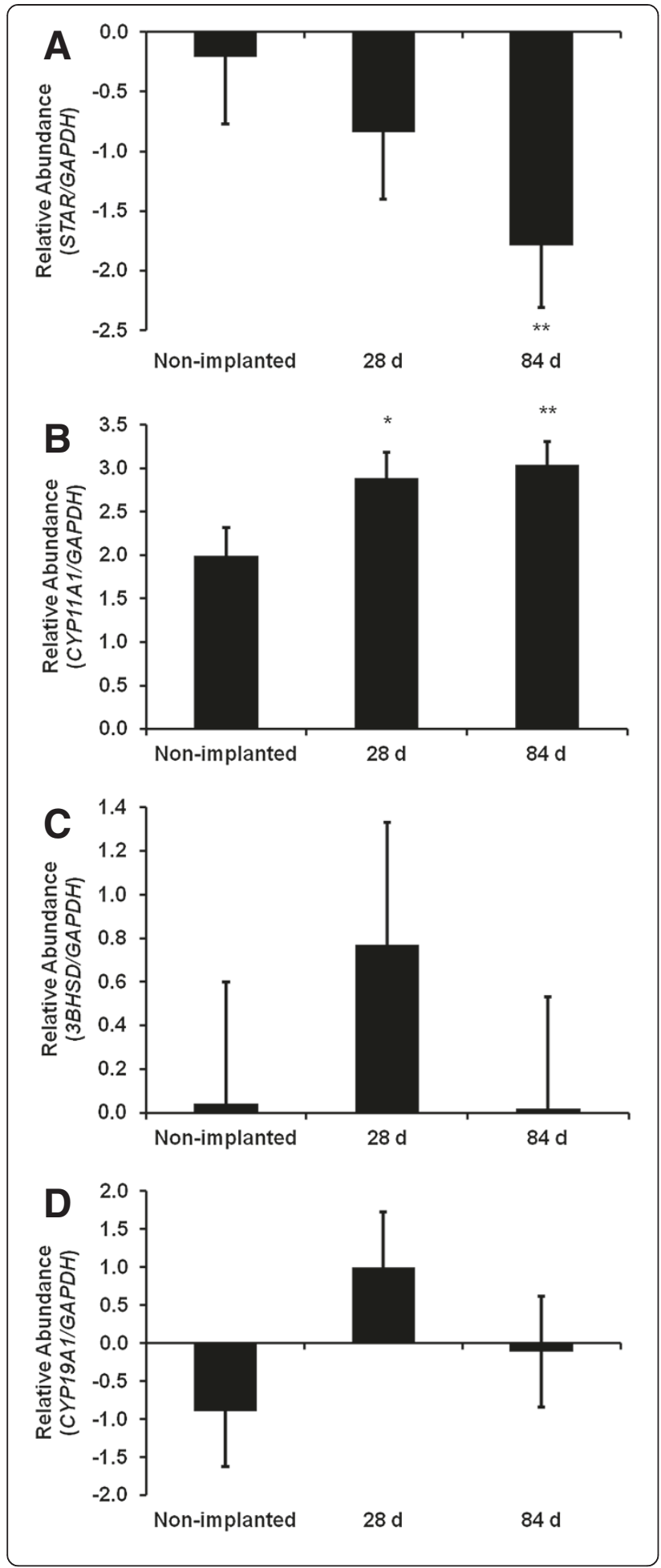

Figure 2 Expression of key steroidogenic enzymes is altered in FSH stimulated granulosa cells from implanted heifers. Bovine small follicle granulosa cells were treated as described in Figure 1. Gene expression data are represented as fold change for each group compared to its respective control to demonstrate individual group response to FSH treatment. Fold change of (A) STAR, (B) CYP11A1, (C) 3BHSD, and (D) CYP19A1 mRNA expression was analyzed by real time-PCR. Statistical significance is presented as the least square mean \pm pooled standard error. ${ }^{*} P<0.10$ and ${ }^{*} P<0.05$ indicates a significant difference when compared with non-implanted heifers.

the increase in medium estrogen detected on $\mathrm{d} 28$ and 84. In the female, ovarian androgens and estrogens regulate release of LH and FSH by feedback mechanisms on the hypothalamus and pituitary and it is not unexpected that exposure to anabolic steroids may disrupt this delicate balance. Elevated concentrations of anabolic and estrogenic steroids from the implants did not have a marked effect on mRNA expression of $3 \beta-H S D$ $(P=0.57$; Figure $2 C)$ the enzyme responsible for converting pregnenolone to progesterone. Next, we evaluated CYP19A1, the enzyme in granulosa cells responsible for converting androgens to estrogen. However, no change in gene expression was detected for CYP19A1 in control versus heifers implanted for 28 or $84 \mathrm{~d}(P=0.22$; Figure 1D). This may be explained in part by the relatively short $3 \mathrm{~h}$ half-life of CYP19A1 in FSH-stimulated bovine granulosa cells compared to the more stable $14 \mathrm{~h}$ half-life demonstrated for CYP11A1 [24].

Additionally, although implant status did not result in significant changes in CYP19A1 mRNA expression, $\mathrm{E}_{2}$ concentrations however, were elevated in both FSH treated implanted groups. This is consistent with previous work in cattle showing that minimal regulation in CYP19A1 gene expression can contribute to measurable differences in $E_{2}$ synthesis $[9,25]$. Normal follicular development relies on increasing concentrations of $E_{2}$ corresponding with follicle maturation and resultant proliferation and differentiation of GC [26]. Additionally, elevated levels of $E_{2}$ in culture medium improves growth of oocytes from early antral follicles [27] supporting an important role of $E_{2}$ in folliculogenesis. However, elevated exogenous concentration of $E_{2}$ can increase the chance of developing cystic follicles and decreases fertility in heifers [6].

In conclusion, these results indicate that follicles which develop in the presence of high concentrations of androgenic and estrogenic steroids via an implant have an altered ability to respond to FSH stimulation as demonstrated by varied steroidogenic enzyme expression and elevated estradiol production. Thus, efforts should be made to avoid the use of implanted heifers to study steroidogenesis in small follicle GC culture systems. 


\section{Competing interests}

The authors declare they have no competing interest.

\section{Authors' contribution}

ADS carried out granulosa cell isolation and cell culture including treatment and collection of cells and media. ADS conducted real-time PCR gene expression analysis. DMH carried out the radioimmunoassays. CAG and JAHG were involved in experimental design, interpretation of data and writing of this manuscript. All authors read and approved the final manuscript.

\section{Acknowledgements}

Research supported by the Oklahoma Agric. Exp. Sta., Stillwater (OKL02789). The authors would like to thank the NIDDK's National Hormone \& Peptide Program and A.F. Parlow for supplying the FSH reagent. Additionally, authors appreciate the Willard Sparks Beef Research Center personnel for overseeing care of experimental animals and lab members for assistance in granulosa cell collection.

\section{Author details}

${ }^{1}$ Department of Animal Science, Oklahoma State University, Stillwater, OK 74078, USA. ${ }^{2}$ Department of Animal and Range Science, New Mexico State University, Las Cruces, NM 88003, USA. ${ }^{3}$ Department of Animal Science, 114B Animal Science Building, Oklahoma State University, Stillwater, OK 74078, USA.

Received: 17 September 2013 Accepted: 3 January 2014

Published: 7 January 2014

\section{References}

1. Johnson BJ, Anderson PT, Meiske JC, Dayton WR: Effect of a combined trenbolone acetate and estradiol implant on feedlot performance, carcass characteristics, and carcass composition of feedlot steers. J Anim Sci 1996, 74(2):363-371.

2. Jones SJ, Johnson RD, Calkins CR, Dikeman ME: Effects of trenbolone acetate on carcass characteristics and serum testosterone and cortisol concentrations in bulls and steers on different management and implant Schemes. J Anim Sci 1991, 69(4):1363-1369.

3. Cooper RA: Some aspects of the use of the growth promoter zeranol in ewe lambs retained for breeding: III. effect on plasma LH levels. Br Vet $J$ 1985, 141(4):424-426.

4. Neumann F: Pharmacological and endocrinological studies on anabolic agents. Environ Qual Saf Suppl 1976, 5:253-264.

5. Katzenellenbogen BS, Katzenellenbogen JA, Mordecai D: Zearalenones: characterization of the estrogenic potencies and receptor interactions of a series of fungal beta-resorcylic acid lactones. Endocrinology 1979, 105(1):33-40.

6. Moran C, Prendiville DJ, Quirke JF, Roche JF: Effects of oestradiol, zeranol or trenbolone acetate implants on puberty, reproduction and fertility in heifers. J Reprod Fertil 1990, 89(2):527-536.

7. Manikkam M, Steckler TL, Welch KB, Inskeep EK, Padmanabhan V: Fetal programming: prenatal testosterone treatment leads to follicular persistence/luteal defects; partial restoration of ovarian function by cyclic progesterone treatment. Endocrinology 2006, 147(4):1997-2007.

8. Reynolds IP, Harrison LP, Mallinson CB, Harwood DJ, Heitzman RJ: The effect of trenbolone acetate on the bovine estrous-cycle. Anim Reprod Sci 1981, 4(2):107-116.

9. Castañon BI, Stapp AD, Gifford CA, Spicer LJ, Hallford DM, Gifford JAH: Follicle-stimulating hormone regulation of estradiol production: possible involvement of WNT2 and $\beta$-catenin in bovine granulosa cells. J Anim Sci 2012, 90:3789-3797.

10. Jaiswal RS, Singh J, Adams GP: Developmental pattern of small antral follicles in the bovine ovary. Biol Reprod 2004, 71(4):1244-1251.

11. Xu Z, Garverick HA, Smith GW, Smith MF, Hamilton SA, Youngquist RS: Expression of follicle-stimulating hormone and luteinizing hormone receptor messenger ribonucleic acids in bovine follicles during the first follicular wave. Biol Reprod 1995, 53(4):951-957.

12. Evans AC, Fortune JE: Selection of the dominant follicle in cattle occurs in the absence of differences in the expression of messenger ribonucleic acid for gonadotropin receptors. Endocrinology 1997, 138(7):2963-2971.

13. Bao B, Garverick HA, Smith GW, Smith MF, Salfen BE, Youngquist RS: Changes in messenger ribonucleic acid encoding luteinizing hormone receptor, cytochrome P450-side chain cleavage, and aromatase are associated with recruitment and selection of bovine ovarian follicles. Biol Reprod 1997, 56(5):1158-1168.

14. Rozen S, Skaletsky H: Primer3 on the WWW for general users and for biologist programmers. Methods Mol Biol 2000, 132:365-386.

15. Gifford CA, Racicot K, Clark DS, Austin KJ, Hansen TR, Lucy MC, Davies CJ, Ott TL: Regulation of interferon-stimulated genes in peripheral blood leukocytes in pregnant and bred, nonpregnant dairy cows. J Dairy Sci 2007, 90(1):274-280.

16. Kubista M, Andrade JM, Bengtsson M, Forootan A, Jonák J, Lind K, Sindelka R, Sjöback R, Sjögreen B, Strömbom L, et al: The real-time polymerase chain reaction. Mol Aspects Med 2006, 27(2-3):95-125.

17. Vandesompele J, De Preter K, Pattyn F, Poppe B, Van Roy N, De Paepe A, Speleman F: Accurate normalization of real-time quantitative RT-PCR data by geometric averaging of multiple internal control genes. Genome Biol 2002, 3(7). research0034.0031 - research0034.0011.

18. Rumsey TS, Elsasser TH, Kahl S: Roasted soybeans and an estrogenic growth promoter affect growth hormone status and performance of beef steers. J Nutr 1996, 126(11):2880-2887.

19. Hongerholt DD, Crooker BA, Wheaton JE, Carlson KM, Jorgenson DM: Effects of a growth hormone-releasing factor analogue and an estradioltrenbolone acetate implant on somatotropin, insulin-like growth factor I, and metabolite profiles in growing Hereford steers. J Anim Sci 1992, 70(5):1439-1448

20. Heitzman RJ, Harwood DJ: Residue levels of trenbolone and oestradiol17beta in plasma and tissues of steers implanted with anabolic steroid preparations. Br Vet J 1977, 133(6):564-571.

21. Heitzman RJ, Harwood DJ, Kay RM, Little W, Mallinson CB, Reynolds IP: Effects of implanting prepuberal dairy heifers with anabolic steroids on hormonal status, puberty and parturition. J Anim Sci 1979, 48(4):859-866

22. Langhout DJ, Spicer $\sqcup$, Geisert RD: Development of a culture system for bovine granulosa cells: effects of growth hormone, estradiol, and gonadotropins on cell proliferation, steroidogenesis, and protein synthesis. J Anim Sci 1991, 69(8):3321-3334.

23. Miller WL: Molecular biology of steroid hormone synthesis. Endocr Rev 1988, 9(3):295-318.

24. Sahmi M, Nicola ES, Price CA: Hormonal regulation of cytochrome P450 aromatase mRNA stability in non-luteinizing bovine granulosa cells in vitro. J Endocrinol 2006, 190(1):107-115.

25. Luo W, Gumen A, Haughian JM, Wiltbank MC: The role of luteinizing hormone in regulating gene expression during selection of a dominant follicle in cattle. Biol Reprod 2011, 84(2):369-378.

26. Richards JS, Midgley AR Jr: Protein hormone action: a key to understanding ovarian follicular and luteal cell development. Biol Reprod 1976, 14(1):82-94.

27. Endo M, Kimura K, Kuwayama T, Monji Y, Iwata H: Effect of estradiol during culture of bovine oocyte-granulosa cell complexes on the mitochondrial DNA copies of oocytes and telomere length of granulosa cells. Zygote 2012:1-9.

doi:10.1186/2049-1891-5-2

Cite this article as: Stapp et al:: Evaluation of steroidogenic capacity after follicle stimulating hormone stimulation in bovine granulosa cells of Revalor $200^{\circledR}$ implanted heifers. Journal of Animal Science and Biotechnology 2014 5:2. 